\title{
THE APPLICATION OF LANGUAGE AS A TOOL FOR ETHNOPOLITICS IN EUROPE - SELECTED REMARKS ${ }^{1}$
}

ABSTRACT The revitalisation of ethnicity as a concept associated with politics has been a meaningful social fact since the early 1960s. This process began at that time in Western Europe. In Central and Eastern Europe the increase of the power of ethnicity had a dramatic effect towards the end of the twentieth century. An important part in this revitalisation is played by the language policy which has a huge influence on the socio-political stabilisation of many entities. Its success, both from the point of view of the interests of the state and of the group distinguished through language, depends on the legal and political culture of both these parties. The initiative should, however, be on the part of the state. In turn, the actions of the authorities negating the importance of language - often the main identity factor of a minority group - foster an uncontrolled growth of the ethnos. This may lead to the increase of ethnically motivated separatism destabilising both separate states and whole regions. Thus, the issue of language is used in ethnopolitics as a starting point either for obtaining political and legal results or for maintaining the ones already achieved. In either case the evaluation of these activities depends on the expectations of the involved parties. Generally it is possible to distinguish three ways of perceiving language as a factor - applied by politicians and ideologically biased intellectuals - influencing the existing political, legal and cultural order. Namely, language may be considered: 1) a recognized threat; 2) an approved means of support; or 3) a postulated opportunity for a beneficial change and its continuity.

Key words: language, ethnicity, politics, politicization, Europe

This is a revised and extended version of a paper presented during the $22^{\text {nd }}$ World Congress of International Political Science Association in Madrid, July 8-12, 2012. 
The call to introduce "local language" in schools was one of the main demands made by national movements. ${ }^{2}$

Miroslav Hroch

\section{INTERPRETATIONS OF KEY TERMS}

Ethnopolitcs and language remain the main operational terms for the research analysis presented below. The analysis aims mainly at proving that both notions are tightly interconnected. The first notion is in fact an amalgamation of two other terms: politics and ethnicity. It is extensively and deliberately used in both political and research contexts. It was introduced to the academic discourse by Joseph Rothschild, the author of the book Ethnopolitics. A Conceptual Framework. ${ }^{3}$ The second notion - within the given configuration - is closely and significantly associated with the first one. There is a popular presumption that language has retained its political role, especially in Central-Eastern Europe due to its deliberate use by skilful politicians and ideologically biased intellectuals. However the association with this particular region remains a long-lasting myth not only among politicians, but also academicians. In fact, at present, language also plays a significant role in the western part of the old continent. This is clearly confirmed by the current political mobilization of some ethno-national communities which have taken the shape of (ethno)regionalist movements, such as Catalonia, the Basque Country and, to a lesser extent, Scotland and the Faroe Islands. Thus the role of language as a basis for political and legal demands is still maintained in Europe as a whole. Naturally some examples of the political use of language presented below in different theoretical configurations require - as I have already underlined - further and deeper analyses.

\subsection{Productive and counter-productive politics. Some historical examples}

Without any extended discussion of the term politics, I assume, following Bernard Crick but not without some misgivings, that for the purposes of this article politics should be defined as an activity which makes it possible to reconcile the interests of various social groups living at an area subject to one power, by granting them the access to the power proportionally to their importance for survival and well-being of the whole community. ${ }^{4}$ Crick defines politics as a mode of divided societies' governance without redundant violence. ${ }^{5}$ Thus he refers it first and foremost to the political systems which

\footnotetext{
M. Hroch, Mate narody Europy. Perspektywa historyczna, trans. by G. Pańko, Wrocław 2003, p. 141 (Zrozumieć Europe).

3 J. Rothschild, Ethnopolitics. A Conceptual Framework, New York 1981.

$4 \quad$ B. Crick, Wobronie polityki, trans. by A. Waśkiewicz, Warszawa 2004, p. 28.

5 Ibid., pp. 45 and 191.
} 
tolerate the opposition and suggests that it should be interpreted in such a way that it would fit mainly the system of government typical of liberal democracy. This view is usually well exemplified in practice, however, it also narrows down the historically verified meaning of the above-mentioned term politics.

The history of mankind has shown very clearly that politics in the form of war is also politics in extenso. This claim was made in the nineteenth century by the Prussian general and military theorist, Carl P.G. von Clausevitz. ${ }^{6}$ Another important reason for getting involved in politics was to fulfil own goals both by political and military means, with the possibility of changing allies as frequently as it is necessary. This brings to mind the rule formulated by Lord Palmerston, the British Prime Minister in the 1850s and 1860s. In his famous phrase he underlined the connection between changing allies and the permanent interests of Great Britain. ${ }^{7}$ The rule as such became a model for well-planned and productive dealing with politics.

In this context, the policy of the Commonwealth of Both Nations, namely the joint Polish-Lithuanian State, also known as the First Polish Commonwealth, stands in direct opposition to this. ${ }^{8}$ This policy, especially starting from the $17^{\text {th }}$ century, led to the ultimate catastrophe in the form of the first (1772) and then the consecutive partitions (1793 and 1795). In that period the ruling elites of the above Commonwealth gradually lost their understanding of the notion of the national interest or raison d'état. The latter notion refers to modern French political tradition and was approved widely as a prerequisite for the safe existence of any state. ${ }^{9}$

The above loss is illustrated by the principle, adopted by these elites, of having changing interests and long lasting alliances with two, in fact, foreign allies. It became the reversal of the rule later formulated by Palmerston. It was manifested by the Commonwealth's policy towards the Habsburg Empire and the Vatican perceived as the main foreign partners and allies for the Commonwealth. It was often implemented not only contrary to geopolitical reasons but also against common sense. At least twice in the $17^{\text {th }}$ century, the Habsburg Monarchy was saved from disaster by the military interventions with Poland's participation: firstly, at the beginning of the Thirty Years' War in 1618-1620 and later on in 1683 thanks to the victory in the Battle of Vienna. ${ }^{10}$ As far as the Vatican's role in the Polish foreign and internal policy is concerned the principle Polonia semper fidelis should be recalled. It has many advocates even in today's Poland, and it means that the Vatican's interests were regarded as more important than those

6 Cf. A. Herberg-Rothe, J.W. Honig, D. Moran (eds.), Clausewitz. The State and War, Stuttgart 2011 (Staatsdiskurse, 17); B. Heuser, Czytając Clausewitza, trans. by P. Budny, Warszawa 2008.

D. Brown, Palmerston. A Biography, New Haven 2010. His original name was Henry John Temple.

8 Cf. J. Topolski, An Outline History of Poland, trans. by O. Wojtasiewicz, Warszawa 1986, p. 73; A. Zamoyski, The Polish Way. A Thousand-year History of the Poles and their Culture, London 1997, p. 92 and further.

9 A. Rzegocki, Racja stanu a polska tradycja myślenia o polityce, Kraków 2008 (Biblioteka Myśli Politycz$n e j, 60)$.

10 Cf. J. Topolski, An Outline History..., pp. 92 and 100-101; A. Zamoyski, The Polish Way..., pp. 133 and 187. 
of the policy of the Polish-Lithuanian Commonwealth. The foreign aspect of it was manifested by the ill-conceived, badly planned and politically irresponsible actions of legate Giuliano Cesarini, which resulted in breaking the peace with Ottoman Turkey by the Polish and Hungarian king, Władysław. Because of his defeat on November 10, 1444, in the battle against the Turks near Varna (Bulgaria) during which he was killed, he was later on called Władysław of Varna. ${ }^{11}$ An example of the second internal aspect of this policy are the activities of the papal nuncio Giovanni Commendone, aimed at undermining the Polish king Zygmunt August's attempts at creating the Polish National Church in the second half of the sixteenth century. ${ }^{12}$

In the long run, the supremacy of the loyalty towards allies over the state's interests has no rational explanation, but it is justified by the habits in the political thinking manifested by the then Polish elites of various orientations. This is, however, another potential topic for consideration and does not refer directly to the subject matter of this article.

\subsection{Ethnicity}

The revival of ethnicity as a concept associated with politics has been an objective social fact since the early 1960s. This process began in Western Europe and its extent surprised the public opinion in many countries. At that time, in the historical memories of many societies, there occurred a sui generis blanking out of the dramatic events from World War II. These events showed the tragic results of the racially and ethnically inspired hatred which seemed to have made it impossible to ever again use ethnicity as a factor differing human communities. ${ }^{13}$ This was especially discouraged both by the Jewish Holocaust and the mass ethnical purges: expulsion of millions of people from their homelands, conducted mainly by the Third Reich and the USSR. The turn of the 1950s and 1960s witnessed a rapid deepening of the decolonisation processes which resulted in the origination of new, young states, especially in Africa. This created an increased interest in ethnicity on the part of the scientific milieu and yielded its analyses both from the European and extra-European comparative perspective, fostering the phenomenon of ethnic mobilisation of small ${ }^{14}$ and stateless, i.e., dependent ${ }^{15}$ European nations inhabiting historically delimited regions in the existing nation-states. It had the form of ethno-regional (or ethno-regionalistic) movements, usually satisfied with obtain-

11 Cf. K. Lepszy, S. Arnold (eds.), Stownik biograficzny historii powszechnej do XVII stulecia, Warszawa 1968, p. 79; W. Czapliński, Zarys dziejów Polski do roku 1864, Kraków 1985, p. 108.

12 Cf. K. Lepszy S. Arnold (eds.), Stownik biograficzny..., pp. 87-88; W. Czapliński, Zarys dziejów Polski..., pp. 196-198.

13 A A.D. Smith, 'Dating the Nation' in D. Conversi (ed.), Ethnonationalism in the Contemporary World. Walker Connor and the Study of Nationalism, London-New York 2004, p. 54 (Routledge Advances in International Relations and Politics).

14 M. Hroch, Mate narody Europy...

15 M. Waldenberg, Narody zależne i mniejszości narodowe w Europie Środkowo-Wschodniej. Dzieje konfliktów i idei, Warszawa 2000. 
ing the status of regional (or territorial) autonomy for the areas where they existed. ${ }^{16}$ It is possible, however, that due to various factors, especially the crisis of legitimacy of power in many existing states, these movements may take a step forward and demand recognition as independent states. Suffice it to mention Montenegro and Kosovo, as faits accomplis (even though they had different origins and external perception) or the long-lasting crisis in Belgium, and the particular part played by the Flemish separatism there, as well as the cases of Scotland, Catalonia or the Basque Country, as facts potentially anticipated. It is worthwhile to mention that in all the above examples - although not on an equal basis indeed - the linguistic factor played an inspiring role for such mobilization. This factor naturally remains a sort of creative agency for these politicians and intellectuals who are motivated by ideological values in particular.

Moreover, at the end of the previous century there occurred new factors stimulating the awakened and politicised ethnicity. These were the fateful events in Central and Eastern Europe, first in Poland in 1980-1981, and finally in 1989 in the whole region which led to the disintegration of the existing constitutional and territorial order. The collapse of the Berlin Wall not only triggered the decomposition of the bipolar order but also encouraged the formation of new nation-states. Their origination reflected the rule formulated by Ernest Gellner, according to which the political units (states in particular) should be equivalent to the national (or nationalities) units. In other words, the origination of a nation-state is the outcome of the principle of so-called congruency, according to which a given national unit having a specific culture matches the territory of the state it occupies. ${ }^{17}$ The origin of the new states in Central and Eastern Europe showed that ethno-national mobilisation may lead to concrete results despite the dramatic circumstances accompanying this process. Thus it is not possible to reject the hypothesis that the tendency to form new nation-states will not be acceptable in Western Europe. At the moment the catalyst may be the fear of a permanent economic or demographic crisis in this part of Europe, e.g., growing debts of some states or the instability of the Eurozone, but also of the uncontrolled influx of immigrants from the non-European states. It seems that the syndrome of delegitimation of the state power, which was crucial for the decomposition of the Central and East European states as they existed before 1989, may have less influence in this case. However, this factor also cannot be neglected, as can be shown by the West European states, to quote Belgium or Spain.

In Central and Eastern Europe the increase of the power of ethnicity as a cause and/ or catalyst for a conflict had an extremely dramatic effect in the events of the 1990s

16 Cf. W. Konarski, 'Status quo Approval, Autonomy or Secession? Ethno-regionalistic Movements as the Form of Nationalism in Europe and Their Impact on the Idea of United Europe' in A. Stępień-Kuczyńska, K. Dośpiał-Borysiak, R. Łoś (eds.), Regiony Europy. Uwarunkowania, wyzwania i perspektywy rozwoju, Toruń 2009 (Dialog Europejski); E. Sagarin, J. Moneymaker, 'Language and Nationalist, Separatist, and Secessionist Movements' in R.L. Hall (ed.), Ethnic Autonomy. Comparative Dynamics, the Americas, Europe, and the Developing World, New York 1979 (Pergamon Policy Studies on Ethnic Issues).

17 E. Gellner, Narody i nacjonalizm, trans. by T. Hołówka, Warszawa 1991, p. 58 (Biblioteka Myśli Wspótczesnej). 
in particular. The most dramatic cause is the breakage or crushing (and not simply a breakup) of the Socialist Yugoslav Federation, as a Polish researcher, Marek Waldenberg, maintains in his book on the disintegration of this state. ${ }^{18}$ In fact the events in the Balkan region have remained - until the annexation of the Crimea peninsula by Russia in 2014 - a cause of remorse for the rest of Europe which witnessed them. This is also why the academic discourse on the links between ethnicity and politics often became intensified and found its point of reference in that very area. This is well examined in the analyses of the earlier and more recent history of this region. ${ }^{19}$

The term ethnicity - in its broadest understanding - [...] refers to any group divisions based on race, language and culture. ${ }^{20}$ Semantically the term ethnicity comes from the Greek ethnos, which means a company, people, or nation. ${ }^{21}$ Its essence is the sense of uniqueness or separateness. This has been noted by, e.g., Nathan Glazer and Daniel P. Moynihan, who perceive ethnicity as [...] a tendency by people to insist on the significance of their distinctiveness and identity and on the rights that derive from this group character. ${ }^{22}$ Both researchers also report that the category of ethnicity was introduced into sociology and political science by David Riesman in $1953 .{ }^{23}$ Ethnicity is a set of features defining the notion of an ethnic group and for that reason these two terms are often used interchangeably. This track was followed by Milton Gordon, for whom an each ethnic group is determined by race, religion, or national origin, or a combination of these categories. ${ }^{24}$ This shows the influence of the American experiences, which, however, due to the increased importance of multiculturalism in Europe, more and more often understood as multiracialism, can also be found in the reality of the Old World.

One of the first researchers who studied ethnic groups was Max Weber. He defines an ethnic group as [...] a human collectivity based on an assumption of common origin, real or imagined. ${ }^{25}$ Weber's view has been reflected in the opinions of other researchers. Ellis Cashmore says that an ethnic group is [...] a self-conscious collection of people united, or closely related, by shared experiences. ${ }^{26}$ According to the Polish researcher Sławoj

18 M. Waldenberg, Rozbicie Jugostawii. Od separacji Stowenii do wojny kosowskiej, Warszawa 2003.

19 Cf. M. Mazower, The Balkans. From the End of Byzantium to the Present Day, London 2000 (Phoenix Press Universal History Series); L. Silber, A. Little, The Death of Yugoslavia, London 1996 (Penguin Current Events); M. Todorova, Batkany wyobrażone, trans. by P. Szymor, M. Budzińska, Wołowiec 2008.

20 E. Allardt, 'What Constitutes a Language Minority?', Journal of Multilingual and Multicultural Development, Vol. 5, No. 3-4 (1984), p. 200, at <http://dx.doi.org/10.1080/01434632.1984.9994151>.

21 Us and Them. The Psychology of Ethnonationalism, New York 1987, p. 19 (Report (Group for the Advancement of Psychiatry. 1984), 123).

22 N. Glazer, D.P. Moynihan, 'Introduction' in iidem (eds.), Ethnicity. Theory and Experience, Cambridge (Mass.) 1975, p. 3.

23 Ibid., p. 1.

24 G. Babiński, Lokalna spoteczność polonijna w Stanach Zjednoczonych Ameryki w procesie przemian, Wrocław 1977, p. 25 (Biblioteka Polonijna, 1).

25 Us and Them..., p. 20.

26 E. Cashmore, 'Ethnicity' in idem (ed.), Dictionary of Race and Ethnic Relations, London 1984, p. 85. 
Szynkiewicz it is [...] a group declaring a shared inherited and unique culture, which is able to spread that belief, and recognising on that basis its uniqueness in the world. ${ }^{27}$ Summing up, the elements of vital importance for an ethnic group are: culture, especially language and religion; genealogy, including race and origin; special personality features and occupied territory. ${ }^{28}$

\subsection{Language}

The linguistic factor, mentioned in Allardt's definition above, cannot be overrated as a leading premise for ethnopolitics. However, against the background of the almost three hundred recent years of history it remains a sort of temptation for politicians and ideologically biased intellectuals who in many cases overuse it. Metaphorically speaking, the language serves as a sui generis vehicle for the way ethnopolitics is performed and may have double, conflict causing and conciliatory, consequences.

Already at the end of the eighteenth century the role of language was underlined by Johann Gottfried Herder and Johann Gottlieb Fichte. It is language that Herder perceived as [...] the main marker of national identity ${ }^{29}$ or a basic element of the term nation, which he understood as a cultural community. According to him [...] a nation is a separate natural being, which aspires to political recognitions on the grounds of having a common language. ${ }^{30}$ Herder did not entirely ignore the meaning of a nation as a political organisation, yet he preferred to treat it as [...] secondary and determined by cultural factors. ${ }^{31}$ Herder's interpretation proves to be particularly useful when we analyse the fates of nations which were deprived of their states, often for hundreds of years, but which preserved their cultures, especially languages, legitimating in this way their aspirations to create their own states. Herder reflected on the fate of such nations in Book 16 of his classic work, i.e., Ideas for the Philosophy of History of Humanity. ${ }^{32}$ What is particularly interesting is that he devoted a separate chapter to the history and culture of the Slavic nations (including the Poles). Herder showed exceptional, for a German, kindness towards them, not to be found in the views of such eminent German intellectuals as August Wilhelm Schlegel or Georg Wilhelm Friedrich Hegel. It is true that he idealised the Slavs, whose languages he could not, nota bene, speak, but the fact that he drew attention to this group of European peoples contributed first of all to [...]

27 S. Szynkiewicz, 'Silva ethnicum' in I. Kabzińska-Stawarz, S. Szynkiewicz (eds.), Konflikty etniczne. Źródta, typy, sposoby rozstrzygania, Warszawa 1996, p. 320 (Biblioteka Etnografii Polskiej, 51).

Cf. A. Kłoskowska, Kultury narodowe u korzeni, Warszawa 1996, p. 19; E. Nowicka, 'Etniczność a sytuacja mniejszościowa', Przeglad Polonijny, Vol. 15, No. 1 (1989), p. 44; R.A. Reminick, Theory of Ethnicity. An Anthropologist's Perspective, Lanham (MD) 1983, pp. 8-13.

P. Spencer, H. Wollman, Nationalism. A Critical Introduction, London 2002, p. 76.

Ibid.

32 J.G. Herder, Myśli o filozofii dziejów, Vol. 2, trans. by J. Gałecki, Warszawa 1962, pp. 330-338 (Biblioteka Klasyków Filozofii). 
the growth of national pride of the South Slavic peoples. ${ }^{33}$ On the other hand, later on Herder's reflections were used instrumentally by the Slavs themselves. As a result, quite unintentionally, Herder had his part in [...] the development of Slavic nationalism in the 19 th century. ${ }^{34}$ It has thus become quite customary that defining the notion of a nation with the use of [...] natural categories, i.e., ones concerning the reality, which existed before the state came to be, such as language, origin, or culture [...] is usually associated with Central and Eastern Europe. ${ }^{35}$ Out of these categories, language, interpreted as an element of broadly understood culture, best reflects the understanding of the term nation used and passed on in this particular part of Europe. However, as I put it clearly above, in today's Western Europe language has also become a deliberately selected tool in the hands of politicians and some intellectuals to awake and mobilize dependent nations and similar communities. I will return to this issue later on.

\subsection{Ethnopolitics}

An initial approach to the perception of ethnopolitics has been offered by Joseph Rothschild, one of the pioneers in this research field. According to him [...] in modern and transitional societies - unlike traditional ones - politicized ethnicity has become the crucial principle of political legitimation and delegitimation of systems, states, regimes, and governments and at the same time has also become an effective instrument for pressing mundane interests in society's competition for power, status, and wealth..$^{36}$ Thus ethnicity understood in such a way refers [...] to the political activities of complex collective groups whose membership is largely determined by real or putative ancestral inherited ties, and who perceive these ties as systematically affecting their place and fate in the political and socioeconomic structures of their state and society. ${ }^{37}$ It seems natural that language remains a significant factor for maintaining the above ties and/or leading to manifold socio-political consequences. Thus language is used in ethnopolitics as a starting point and premise either for obtaining concrete political and legal results or for maintaining the ones already achieved. In either case evaluation of these activities depends on the point of view and expectations of the involved parties. To put it more directly, the organizational expression of ethnopolitics is the ethnopolitical party as John T. Ishiyama and Marijke Breuning underline. ${ }^{38}$ In the above understanding of ethnopolitics, its participants remain in conflict rather than cooperate. However, both the above cited authors are more optimistic by saying that [...] although ethnopolitics can be conflictual, it can also be cooperative. ${ }^{39}$

33 T. Namowicz, Johann Gottfried Herder. Z zagadnień przetomu oświecenia w Niemczech w drugiej potowie XVIII wieku, Olsztyn 1995, p. 157 (Biblioteka Olsztyńska, 29).

Ibid.

U. Altermatt, Sarajewo przestrzega. Etnonacjonalizm w Europie, trans. by G. Sowinski, Kraków 1998, p. 37 (Biblioteka Myśli Politycznej).

J. Rothschild, Ethnopolitics..., p. 2.

Ibid., p. 9.

J.T. Ishiyama, M. Breuning, Ethnoplitics in the New Europe, Boulder (Co.)-London 1998, p. 4.

Ibid. 


\section{POLITICIZATION OF LANGUAGE - SELECTED ASPECTS AND EXAMPLES}

Consequently, aspiring to any form of political emancipation (own state and/or regional/territorial autonomy) is combined either with deliberate maintaining of language as a means of everyday communication or in revitalising it so that it can fulfil the above function.

Language has thus become an important factor determining broadly understood language politics which was performed by manifold states and organizations for their own sake. ${ }^{40}$ Hence the importance of language was used to legitimise the newly-won state in various forms and had various consequences. One of these applied forms was the national language, which from the legal point of view had the rank of an official language in the whole country. Such language however, in its purely ideological understanding, reflected the privileged position of a specific group of people, called the dominant or state nation. The latter term is perceived historically as a synonym of the term political nation. However, it should be noted that interchanging the adjectives "state" and "political" with reference to the term nation does not seem to be entirely justified, hence some further comments are necessary.

In the general debate about the definitions of the term nation the most frequent dichotomy is the opposition of two adjectives used to denote it: the political and the ethnic nation. The origins of such a contrast should be sought in the tradition stemming from the works of Jean Jacques Rousseau and Johann Gotfried Herder. The former defined the role of nation as a political community (and not just a state one) and for the latter a particular part was played by understanding nation as a cultural community. Referring to both classics, more than hundred years ago a German researcher, Friedrich Meinecke, formulated two concepts of nation modified as far as their names are concerned: a state one (understood by him as an entity with common political history and constitution), and a cultural one, frequently termed ethnic. ${ }^{41}$ It is worthwhile to underline that a very broad discussion of such dichotomy, supported by extensive exemplification, was examined precisely by many others, including two researchers of Czech origin, Jaroslav Krejči and Vitézslav Velimsky, in their work Ethnic and Political Nations in Europe. ${ }^{42}$

Applying the two schools of thinking about nation described above and following the term state adopted by Meinecke may lead to the replacement of the term political (or civic) nation with the term state nation. In fact both terms are synonymous for Meinecke. However, on the other hand, one should agree with the Polish sociologist Antonina Kłoskowska, according to whom the concept of state nation should be understood as a term denoting an early form of ethnically diversified community sub-

40 R. Szul, Jezzy, naród, państwo. Jezzyk jako zjawisko polityczne, Warszawa 2009, pp. 58-65 and passim.

${ }^{41} \quad$ U. Altermatt, Sarajewo przestrzega..., pp. 35-36.

42 J. Krejči, V. Velímský, Ethnic and Political Nations in Europe, London 1981. 
ordinated to one state, the administrative policy of which often leads to gradual unification of culture. ${ }^{43}$ Another Polish historian and politologist (mentioned already), Marek Waldenberg, uses, in turn, the term of titular nation (termed state nation by the others). According to him, it is such a nation which, in the historical perspective, aspired (or, more precisely, part of which aspired) to create a given state or proclaimed it, which as a rule treats it as a precious national value and as a rule is made up of the majority of its inhabitants. Some of the members of a state nation also believe that only this nation should be the rightful sovereign in that state and the other national communities inhabiting it should be treated as citizens of a lower category. ${ }^{44}$

The latter sentence reflects many examples of such deliberate settling of the language question in the newest European history. The decomposition of Yugoslavia and removal of Serbo-Croatian from the position of an official language in the 1990s seems to have been carried out especially ruthlessly by the political inspirers of this process. The differences between imagined and real language were magnified and institutionalized by the newly born state elites in order to deepen and maintain barriers between the people living in the territory of former Yugoslavia. Thus the proclamation of appearance of three new languages, namely Croatian, Bosnian and Serbian, simultaneously demonstrated the will of dominance of one ethnonational group over the other. ${ }^{45}$ The role allocated to these languages may be described as entirely monistic [underl. by WK].

The pluralistic [underl. by WK] role of languages comes to mind if only to remind that in some European states there is more than one constitutionally recognized official/national language, e.g. in Switzerland or Finland. The Swiss example is a well-known and unique confirmation of cultural and linguistic pluralism reflected by the four national languages being in use (art. 4). ${ }^{46}$ According to the Finnish Constitution there are two national languages, namely Finnish and Swedish (art. 17). ${ }^{47}$ The long-lasting coexistence of speakers of these two languages was confirmed in such a conciliatory way. However, there is one territorial exception from the above rule. In the Aaland Islands, which belong to Finland and enjoy the status of regional autonomy, Swedish is the only official language. ${ }^{48}$ Such an arrangement is the result of a kind of legal concession from the newly born Finnish state towards a territory where the majority of the population spoke only Swedish. Thus in fact Finnish and Swedish share the constitutional position of two national languages on the whole territory of Finland with the exception of the Aaland Islands.

43 A. Kłoskowska, Kultury narodowe..., pp. 29-30.

44 M. Waldenberg, Narody zależne..., pp. 29-30.

45 P. Spencer, H. Wollman, Nationalism..., p. 80.

46 Switzerland Constitution, at <http://www.servat.unibe.ch/icl/sz00000_html>, 18 October 2013.

47 Konstytucja Republiki Finlandii z 11 czerwca 1999 roku, trans. by J. Osiński, Warszawa 2003, p. 70.

48 Cf. C. Janson, 'The Autonomy of Áland. A Reflexion of International and Constitutional Law', Nordisk Tidsskrift for International Ret. Acta scandinavica juris gentium, Vol. 51, Fasc. 1-2 (1982), p. 18; W. Konarski, 'Legal and Educational Status of the Swedish-Speaking Minority in Finland' in P. Wawrzyk (ed.), European Studies. Selected Research Problems, Warszawa 2009, p. 24. 
Bilingualism is also constitutionally sanctioned in Ireland, although its origin and practical message are entirely different than in Finland. The Irish Constitution (Bunreacht na hÉireann) provides that: The Irish language as the national language is the first official language (art. 8.1) and furthermore: The English language is recognised as a second official language (art. 8.2). ${ }^{49}$ Thus, unlike in Finland, both languages are unequal legally and de nomine Irish enjoys a privileged position. However, in practice the supremacy of English is overwhelming. Due to the far-reaching plans of the founding fathers of the Irish statehood - Eamon de Valera in particular - the restoration of Irish (Gaelic) as a commonly spoken language [...] would have the most profound effect on Ireland's progress during the years ahead [... $]^{50}$ and furthermore [...] language had to play a major role in a nation-state-building project, a homogenizing tool, albeit one that would tend to exclude non-Catholics and non-Gaelic speakers. ${ }^{51}$ The purely ideological approach to the process of the language revival demonstrated above was confirmed in practice. ${ }^{52}$ Unlike in the case of the successful restoration of Hebrew in Israel $^{53}$ the Irish language is spoken by a minority of citizens of independent Ireland. ${ }^{54}$ However, speaking Irish still remains a demonstration of nationalistic feelings for those who can do it especially on a daily basis.

\section{THREE FORMS OF PERCEIVING LANGUAGE AS A PROPOSAL FOR CONSIDERATION}

Generally, language remains a constant object of interest for politicians and ideologically motivated intellectuals. This naturally results in their growing influence - via the language issue - on the existing political, legal, and cultural order. As a factor instrumentally and actively shaped by them, the perception of language may have three general forms (in this order): 1) a recognized threat; 2) an approved means of support; or 3) a postulated opportunity for a beneficial change and its continuity. The exemplification presented below refers to selected cases within Europe. Thus, it does not exhaust the topic, but it may encourage more precise analyses of these three cases.

49 Cf. J. Casey, Constitutional Law in Ireland, Dublin 2000, pp. 73-74; J.A. Foley, S. Lalor (eds.), Gill \& Macmillan Annotated Constitution of Ireland, 1937-1994. With Commentary, Dublin 1995, p. 32.

50 D. Ferriter, Judging Dev. A Reassessment of the Life and Legacy of Eamon de Valera, Dublin 2007, pp. 305 and further.

51 P. Spencer, H. Wollman, Nationalism..., p. 78. See also: M. Kornprobst, 'Episteme, Nation-Builders and National Identity. The Re-construction of Irishness', Nations and Nationalism, Vol. 11, No. 3 (2005), at <http://dx.doi.org/10.1111/j.1354-5078.2005.00211.x>.

52 J. Casey, Constitutional Law..., pp. 74-77. See also: W. Konarski, System konstytucyjny Irlandii, Warszawa 2005, pp. 26-27 (Systemy Konstytucyjne Państw Świata).

53 A. Pelaia, The Hebrew Language. History and Origins of the Hebrew Language, About - Judaism, at <http://judaism.about.com/od/jewishhistory/a/Hebrew-Language-Origins-History.htm>, 18 October 2013.

54 The Irish Language Today, Ask About Ireland, at <http://www.askaboutireland.ie/learning-zone/ secondary-students/irish/an-cultur-gaelach/translation-irish-languag/the-irish-language-today/>, 18 October 2013. 


\subsection{Language as a recognized threat}

The phenomenon of glottophagia, i.e, the suppression of the minority language by that of the majority [...] refers to the first option of those mentioned above. ${ }^{55}$ This special case can be described as ethnopolitics of language based exclusivism. Such a policy may result in the marginalization or assimilation of small dependent nations or minorities, which use a different language than the dominant/state/titular nation.

Legal provisions hindering the teaching of minority languages or even directed at their eradication are becoming particularly dangerous. The examples of treating language as a real threat for the existing political, legal, and cultural order in the European circumstances are: Irish in the United Kingdom of Great Britain and Ireland in the 19th century (see below), Breton and Corsican in post-revolutionary France, ${ }^{56}$ and, also, Polish in the Prussian and Russian partition zones after the Napoleonic wars. $^{57}$

A very dramatic example of such a situation is the 19th-century policy of the British government towards Ireland, which was at that time part of Great Britain. British intentions to implement in 1831 a system of so called national schools, which was meant to denationalise the Irish, are now unanimously condemned. As the Polish linguists Ewa and Alfred Majewicz wrote, the then British authorities introduced in Ireland an educational system [...] the only aim of which was to eradicate the Irish language from the life of the Irish children. ${ }^{58}$ As a result, seventy years later the number of Irish speakers had decreased drastically. Out of 4.6 million inhabitants of the island only 0.6 million people could speak it and there were ca 0.03 million Irish monolinguals. ${ }^{59}$ As mentioned above, the efforts to make Irish a commonly used language, which began at the time Ireland became independent, have been quite counter-productive so far. It should be remembered that the need to master this language is appreciated by the widely understood political, administrative and intellectual elites in Ireland.

Apart from the historical examples, there are also numerous cases from the modern times. ${ }^{60}$ In the context of language rights of Polish-speaking communities abroad, the recent policy in that matter of the Lithuanian Republic has been particularly criticised. The new legal regulations adopted in 2011, limiting the possibility to teach in Polish in

55 P.H. Nelde, 'Language Contact Means Language Conflict', Journal of Multilingual and Multicultural Development, Vol. 8, No. 1-2 (1987), at <http://dx.doi.org/10.1080/01434632.1987.9994273>, p. 38.

56 Cf. J. Gwegen, La langue bretonne face á ses oppresseurs, Quimper 1975; M. Labro, La question corse, Paris 1977 (Minorités).

57 Cf. J. Topolski, An Outline History..., pp. 162, 182-183, 188 and passim; A. Zamoyski, The Polish Way..., p. 327 and passim.

58 E. Majewicz, A.F. Majewicz, Jezzyki celtyckie na Wyspach Brytyjskich, Wrocław 1983, p. 10 (Nauka dla Wszystkich, 368).

59 Ibid.

$60 \quad$ P.H. Nelde, 'Language Contact..., p. 38. 
that country, have been negatively evaluated both by the Polish minority in Lithuania and in Poland itself. ${ }^{61}$

\subsection{Language as an approved means of support}

In the second case, language is perceived as a means of support for the existing political, legal, and cultural order approved not only by the state's power elite but also by a large majority of members of the political class. ${ }^{62}$ In this way the rights of such communities are made equal to those of a state nation, or, if such a nation does not exist, all ethnic groups inhabiting a given state are made equal. This can be described as ethnopolitics of language-based pluralism. Among pertinent and enduring examples from Europe there are especially the previously mentioned language groups in Switzerland ${ }^{63}$ and the Swedish-speaking Finns, but only those from the Finnish interior, i.e., outside the Aaland Islands. ${ }^{64}$ Full ethnic language pluralism is safeguarded by the constitutionally guaranteed bi- (Finland) or multi-lingualism (Switzerland) and its successful implementation. This means that a given linguistic community is identified not only by means of self-categorisation or self-description. ${ }^{65}$ What becomes extremely important is the external categorisation which is, e.g., a consequence of legal actions of a given state.

\subsection{Language as a postulated opportunity for a beneficial change and its continuity}

There exists the third form, more or less intermediary, in which special rights are granted to the groups stressing the rank of their own language (although not solely due to that), which encourages them to accept the status quo in a given state. However, this approval is not guaranteed forever, which is currently noticeable in Catalonia. Ethnopolitics of language based inclusivism is the term which I have adopted to denote this special case. Selected examples from Europe are: the Galicians and to a lesser extent the Basques and Catalans in Spain, ${ }^{66}$ the Welsh and again to lesser ex-

${ }_{61}$ M. Kallonen, 'Minority Protection and Linguistic Rights in Lithuania', Noves SL. Revista de Sociolingüistica, Vol. 3 (2004), at <http://www.gencat.cat/llengua/noves/noves/hm04tardor/docs/ kallonen.pdf>, 12 October 2013.

62 The term political class is understood here as a group of full time public representatives who belong either to the governing or opposition groups. See W. Konarski, 'Polityka i politycy w Polsce - analiza krytyczna' in A. Rothert, A. Wierzchowska (eds.), Rzadzenie w przestrzeni ponadnarodowej, Warszawa 2013 (Studia Politologiczne, 27).

63 R. Szul, Język, naród, państwo..., pp. 236-243.

64 Cf. E. Allardt, 'Bilingualism in Finland. The Position of Swedish as a Minority Language' in W.R. Beer, J.E. Jacob (eds.), Language Policy and National Unity, Totowa (NJ) 1985; J.M. Jansson, 'Language Legislation' in J. Uotila (ed.), The Finnish Legal System, Helsinki 1985.

65 E. Allardt, 'What Constitutes..., pp. 201-203.

66 Cf. W. Dobrzycki, 'Separatyzmy i problemy narodowościowe w Hiszpanii' in H. Szczerbiński (ed.), "Problemy narodowościowe w Europie i ich wptyw na stosunki międzynarodowe" na przetomie XX i XXI wieku, Warszawa 2009, pp. 193, 199, 205 and passim; M. Hroch, Mate narody Europy..., pp. 59-65; 
tent the Scots in Great Britain, ${ }^{67}$ the Swedish-speaking inhabitants of the Aaland Islands in Finland, the Faroese from the Faroe Islands and the Greenlanders within the Kingdom of Denmark, ${ }^{68}$ or the German-speaking inhabitants of South Tyrol in Italy. ${ }^{69}$ This type of ethnopolitics involves the facilitation of teaching minority languages and cultivation of cultural traditions and customs. The most advanced level is the process of legal and political decentralisation, which leads to achieving territorial or regional autonomy with special rights offered to language communities. The latter is known in the United Kingdom's political tradition as devolution understood as the transfer to a subordinate elected body, on a geographical basis, of functions at present exercised by ministers and Parliament. ${ }^{70}$ In connection with the last mentioned aspect, the approval by the authorities of the activities of the political parties representing minority groups is particularly important.

\section{CONCLUSIONS}

Those who use language as an important factor for shaping ethnopolitics have a huge influence on the socio-political stabilisation of many states and regions. Briefly speaking, its success, both from the point of view of the interests of the state and of the group distinguished through the language, depends on how high the legal and political culture of both these parties is. The initiative should, however, be on the part of the state. In turn, the actions of the authorities negating the importance of language - often the main identity factor of minority group - foster the uncontrolled growth of the ethnos. As previously mentioned, this may lead to an increase in the rank of ethnically motivated separatism destabilising both separate states and whole regions within a continent. Thus, in ethnopolitics language is used as a starting point and premise either for obtaining concrete political and legal results or for maintaining the ones already achieved. In either case evaluation of these activities depends on the point of view and expectations of the involved parties. Depending on the activities of those involved, language may be a functional or dysfunctional prerequisite for ethnopolitics as a process in action. What is more, this conclusion is constantly verified in front of our eyes.

M. Myśliwiec, Katalonia na drodze do niepodlegtości?, Bytom 2006, pp. 118-160; R. Szul, Jezyk, naród, państwo..., pp. 153-154, 196, 296-300.

67 Cf. M. Hroch, Mate narody Europy..., pp. 54-58; M. Kaczorowska, 'Problemy narodowościowe w Wielkiej Brytanii - Szkocja, Walia' in H. Szczerbiński (ed.), "Problemy narodowościowe..., pp. 282, 286-287, 314-315.

68 R. Szul, Jezzyk, naród, państwo..., pp. 205-206.

69 D. Popławski, 'Problem południowego Tyrolu w stosunkach włosko-austriackich' in H. Szczerbiński (ed.), "Problemy narodowościowe..., passim.

70 V. Bogdanor, Devolution in the United Kingdom, Oxford-New York 2001, p. 2. 


\section{BIBLIOGRAPHY}

Allardt E., 'Bilingualism in Finland. The Position of Swedish as a Minority Language' in W.R. Beer, J.E. Jacob (eds.), Language Policy and National Unity, Totowa (NJ) 1985.

Allardt E., 'What Constitutes a Language Minority?', Journal of Multilingual and Multicultural Development, Vol. 5, No. 3-4 (1984), at <http://dx.doi.org/10.1080/01434632.1984.999 $4151>$.

Altermatt U., Sarajewo przestrzega. Etnonacjonalizm w Europie, trans. by G. Sowinski, Kraków 1998 (Biblioteka Myśli Politycznej).

Babiński G., Lokalna spoteczność polonijna w Stanach Zjednoczonych Ameryki w procesie przemian, Wrocław 1977 (Biblioteka Polonijna, 1).

Bogdanor V., Devolution in the United Kingdom, Oxford-New York 2001.

Brown D., Palmerston. A Biography, New Haven 2010.

Casey J., Constitutional Law in Ireland, Dublin 2000.

Cashmore E., 'Ethnicity' in idem (ed.), Dictionary of Race and Ethnic Relations, London 1984.

Crick B., Wobronie polityki, trans. by A. Waśkiewicz, Warszawa 2004.

Czapliński W., Zarys dziejów Polski do roku 1864, Kraków 1985.

Dobrzycki W., 'Separatyzmy i problemy narodowościowe w Hiszpanii’ in H. Szczerbiński (ed.), "Problemy narodowościowe w Europie i ich wptyw na stosunki międzynarodowe" na przetomie XX i XXI wieku, Warszawa 2009.

Ferriter D., Judging Dev. A Reassessment of the Life and Legacy of Eamon de Valera, Dublin 2007. Foley J.A., Lalor S. (eds.), Gill \& Macmillan Annotated Constitution of Ireland, 1937-1994. With Commentary, Dublin 1995.

Gellner E., Narody i nacjonalizm, trans. by T. Hołówka, Warszawa 1991 (Biblioteka Myśli Wspótczesnej).

Glazer N., Moynihan D.P., 'Introduction' in iidem (eds.), Ethnicity. Theory and Experience, Cambridge (Mass.) 1975.

Gwegen J., La langue bretonne face á ses oppresseurs, Quimper 1975.

Herberg-Rothe A., Honig J.W., Moran D. (eds.), Clausewitz. The State and War, Stuttgart 2011 (Staatsdiskurse, 17).

Herder J.G., Myśli o filozofii dziejów, Vol. 2, trans. by J. Gałecki, Warszawa 1962 (Biblioteka Klasyków Filozofii).

Heuser B., Czytajac Clausewitza, trans. by P. Budny, Warszawa 2008.

Hroch M., Mate narody Europy. Perspektywa historyczna, trans. by G. Pańko, Wrocław 2003 (Zrozumieć Europę).

The Irish Language Today, Ask About Ireland, at <http://www.askaboutireland.ie/learning-zone/secondary-students/irish/an-cultur-gaelach/translation-irish-languag/the-irish-language-today $/>$.

Ishiyama J.T., Breuning M., Ethnopolitics in the New Europe, Boulder (Co.), London 1998.

Janson C., 'The Autonomy of Âland. A Reflexion of International and Constitutional Law', Nordisk Tidsskrift for International Ret. Acta scandinavica juris gentium, Vol. 51, Fasc. 1-2 (1982). 
Jansson J.M., 'Language Legislation' in J. Uotila (ed.), The Finnish Legal System, Helsinki 1985. Kaczorowska M., 'Problemy narodowościowe w Wielkiej Brytanii - Szkocja, Walia' in H. Szczerbiński (ed.), "Problemy narodowościowe w Europie i ich wptyw na stosunki międzynarodowe" na przetomie XX i XXI wieku, Warszawa 2009.

Kallonen M., 'Minority Protection and Linguistic Rights in Lithuania', Noves SL. Revista de Sociolingüistica, Vol. 3 (2004), at <http://www.gencat.cat/llengua/noves/noves/hm04tardor/ docs/kallonen.pdf>.

Kłoskowska A., Kultury narodowe u korzeni, Warszawa 1996.

Konarski W., 'Legal and Educational Status of the Swedish-Speaking Minority in Finland' in P. Wawrzyk (ed.), European Studies. Selected Research Problems, Warszawa 2009.

Konarski W., 'Polityka i politycy w Polsce - analiza krytyczna' in A. Rothert, A. Wierzchowska (eds.), Rządzenie w przestrzeni ponadnarodowej, Warszawa 2013 (Studia Politologiczne, 27). Konarski W., 'Status quo Approval, Autonomy or Secession? Ethno-regionalistic Movements as the Form of Nationalism in Europe and Their Impact on the Idea of United Europe' in A. Stępień-Kuczyńska, K. Dośpiał-Borysiak, R. Łoś (eds.), Regiony Europy. Uwarunkowania, wyzwania i perspektywy rozwoju, Torun 2009 (Dialog Europejski).

Konarski W., System konstytucyjny Irlandii, Warszawa 2005 (Systemy Konstytucyjne Państw Świata).

Konstytucja Republiki Finlandii z 11 czerwca 1999 roku, trans. by J. Osiński, Warszawa 2003.

Kornprobst M., 'Episteme, Nation-Builders and National Identity. The Re-construction of Irishness', Nations and Nationalism, Vol. 11, No. 3 (2005), at <http://dx.doi.org/10.1111/ j.1354-5078.2005.00211.x>.

Krejči J., Velímský V., Ethnic and Political Nations in Europe, London 1981.

Labro M., La question corse, Paris 1977 (Minorités).

Lepszy K., Arnold S. (eds.), Stownik biograficzny historii powszechnej do XVII stulecia, Warszawa 1968.

Majewicz E., Majewicz A.F., Jezzyki celtyckie na Wyspach Brytyjskich, Wrocław 1983 (Nauka dla Wsystkich, 368).

Mazower M., The Balkans. From the End of Byzantium to the Present Day, London 2000 (Phoenix Press Universal History Series).

Myśliwiec M., Katalonia na drodze do niepodlegtości?, Bytom 2006.

Namowicz T., Johann Gottfried Herder. Z zagadnień przetomu oświecenia w Niemczech w drugiej potowie XVIII wieku, Olsztyn 1995 (Biblioteka Olsztyńska, 29).

Nelde P.H., 'Language Contact Means Language Conflict', Journal of Multilingual and Multicultural Development, Vol. 8, No. 1-2 (1987), at <http://dx.doi.org/10.1080/01434632.19 87.9994273>.

Nowicka E., 'Etniczność a sytuacja mniejszościowa', Przegląd Polonijny, Vol. 15, No. 1 (1989).

Pelaia A., The Hebrew Language. History and Origins of the Hebrew Language, About - Judaism, at <http://judaism.about.com/od/jewishhistory/a/Hebrew-Language-Origins-History.htm>.

Popławski D., 'Problem południowego Tyrolu w stosunkach włosko-austriackich' in H. Szczerbiński (ed.), "Problemy narodowościowe w Europie i ich wptyw na stosunki międzynarodowe" na przetomie XX i XXI wieku, Warszawa 2009.

Reminick R.A., Theory of Ethnicity. An Anthropologist's Perspective, Lanham (MD) 1983. 
Rothschild J., Ethnopolitics, A Conceptual Framework, New York 1981.

Rzegocki A., Racja stanu a polska tradycja myślenia o polityce, Kraków 2008 (Biblioteka Myśli Politycznej, 60).

Sagarin E., Moneymaker J., 'Language and Nationalist, Separatist, and Secessionist Movements' in R.L. Hall (ed.), Ethnic Autonomy. Comparative Dynamics, the Americas, Europe, and the Developing World, New York 1979 (Pergamon Policy Studies on Ethnic Issues).

Silber L., Little A., The Death of Yugoslavia, London 1996 (Penguin Current Events).

Smith A.D., 'Dating the Nation' in D. Conversi (ed.), Ethnonationalism in the Contemporary World. Walker Connor and the Study of Nationalism, London-New York 2004 (Routledge Advances in International Relations and Politics).

Spencer P., Wollman H., Nationalism. A Critical Introduction, London 2002.

Switzerland Constitution, at <http://www.servat.unibe.ch/icl/sz00000_.html>.

Szacki J., Historia myśli socjologicznej, Vol. 1, Warszawa 1983

Szul R., Jezzyk, naród, państwo. Jezzyk jako zjawisko polityczne, Warszawa 2009.

Szynkiewicz S., 'Silva ethnicum' in I. Kabzińska-Stawarz, S. Szynkiewicz (eds.), Konflikty etniczne. Źródta, typy, sposoby rozstrzygania, Warszawa 1996 (Biblioteka Etnografii Polskiej, 51). Todorova M., Batkany wyobrażone, trans. by P. Szymor, M. Budzińska, Wołowiec 2008.

Topolski J., An Outline History of Poland, trans. by O. Wojtasiewicz, Warszawa 1986.

Us and Them. The Psychology of Ethnonationalism, New York 1987 (Report (Group for the Advancement of Psychiatry. 1984), 123).

Waldenberg M., Narody zależne i mniejszości narodowe w Europie Środkowo-Wschodniej. Dzieje konfliktów i idei, Warszawa 2000.

Waldenberg M., Rozbicie Jugostawii. Od separacji Stowenii do wojny kosowskiej, Warszawa 2003. Zamoyski A., The Polish Way. A Thousand-year History of the Poles and their Culture, London 1997.

Wawrzyniec Konrad KONARSKI is Professor of Political Science and head of the Chair of Ethnocultural Politics at the Jagiellonian University in Cracow, Poland. His research enquiries concern the linkages between ethnicity and politics within and outside Europe. He has published and edited more than ten of his own monographs and many other articles, expert appraisements, and critical reviews including Pragmatycy $i$ idealiści. Rodowód, typologia $i$ ewolucja ugrupowań politycznych nacjonalizmu irlandziego $w$ XX wieku [Pragmatists and Idealists: Origins, Typology and Evolution of the Political Parties in the Twentieth Century Irish Nationalism] (Pułtusk-Warszawa 2001), System konstytucyjny Irlandii [The Constitutional System of Ireland] (Warszawa 2005), Kryzys przywództwa we wspótczesnej polityce [The Crisis of Leadership in the Contemporary Politics] (Warszawa 2011), Politolog o polityce. Wywiady, komentarze, opinie i ekspertyzy (2008-2014) [Political Scientist on Politics. Interviews, Comments, Opinions and Expertises (2008-2014)] (Warszawa 2014). He is a frequent commentator of politics in Polish and foreign media. 